\title{
Article \\ Genotype by Environment Interaction Effect on Grain Iron and Zinc Concentration of Indian and Mediterranean Lentil Genotypes
}

\author{
Soma Gupta ${ }^{1,2}$, Shouvik Das ${ }^{1}$, Harsh Kumar Dikshit ${ }^{1, * \mathbb{C}}$, Gyan Prakash Mishra ${ }^{1, * \mathbb{C}}$, Muraleedhar S. Aski ${ }^{1}$ (D),

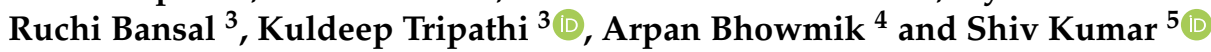 \\ 1 Division of Genetics, ICAR-Indian Agricultural Research Institute, New Delhi 110012, India; \\ somugupta24@gmail.com (S.G.); shouvikdas51@gmail.com (S.D.); murali2416@gmail.com (M.S.A.) \\ 2 ICAR-Indian Institute of Seed Science, Mau 275103, India \\ 3 Division of Germplasm Evaluation, ICAR-National Bureau of Plant Genetic Resources, \\ New Delhi 110012, India; ruchibansal06@gmail.com (R.B.); Kuldeep.Tripathi@icar.gov.in (K.T.) \\ 4 Division of Design of Experiments, ICAR-Indian Agricultural Statistics Research Institute, \\ New Delhi 110012, India; arpan.stat@gmail.com \\ 5 Biodiversity and Integrated Gene Management Program, International Center for Agricultural Research in \\ the Dry Areas, Avenue Hafiane Cherkaoui, Rabat 10112, Morocco; sk.agrawal@cgiar.org \\ * Correspondence: harshgeneticsiari@gmail.com (H.K.D.); gyan.gene@gmail.com (G.P.M.)
}

\section{check for}

updates

Citation: Gupta, S.; Das, S.; Dikshit, H.K.; Mishra, G.P.; Aski, M.S.; Bansal, R.; Tripathi, K.; Bhowmik, A.; Kumar, S. Genotype by Environment Interaction Effect on Grain Iron and Zinc Concentration of Indian and Mediterranean Lentil Genotypes. Agronomy 2021, 11, 1761. https:// doi.org/10.3390/agronomy11091761

Academic Editor: Aurora Díaz Bermúdez

Received: 9 June 2021

Accepted: 5 August 2021

Published: 31 August 2021

Publisher's Note: MDPI stays neutral with regard to jurisdictional claims in published maps and institutional affiliations.

Copyright: (c) 2021 by the authors. Licensee MDPI, Basel, Switzerland. This article is an open access article distributed under the terms and conditions of the Creative Commons Attribution (CC BY) license (https:// creativecommons.org/licenses/by/ $4.0 /)$
Abstract: Lentil grains with high nutritional value qualify as a promising candidate for alleviation of micronutrient malnutrition in South Asia and North Africa. Genetic variation for micronutrient concentration in germplasm is prerequisite for biofortification of this crop. In the present study, ninetysix lentil genotypes consisting of Indian (released varieties, advanced breeding lines and germplasm lines) and Mediterranean (germplasm lines and landraces) lines were evaluated for grain iron (Fe) and zinc ( $\mathrm{Zn}$ ) concentrations and the stability of these traits was studied across three different locations in India. The pooled analysis of variance revealed significant genotype, environment and genotype by environment interaction (GEI) mean squares for both the micronutrients. Stability analysis employing the AMMI model elucidated the first two interaction principal components as significant and cumulatively explained $100 \%$ of GEI variation. The first two components explained $55.9 \%$ and $44.1 \%$ of the GEI sum of squares for grain iron and $50.8 \%$ and $49.2 \%$ for grain zinc concentration, respectively. No correlation between grain iron and zinc concentration was observed. Among 96 lines, genotypes IG 49, P 16214, ILL 147 and P 2118 were found to be relatively stable, having higher mean iron and zinc concentrations with low modified AMMI stability value (MASV), modified AMMI stability index (MASI) and genotype selection index (GSI). The identified promising genotypes (high Fe: P 16214, IG 115, P 2127 and IC 560812 and high Zn: P 8115, P 3234, LL 461 and IC 560812) can be utilized for studying the genetics of grain $\mathrm{Fe}$ and $\mathrm{Zn}$ concentration by developing mapping populations and for biofortification of Indian lentil.

Keywords: lentil; grain Fe and Zn concentration; AMMI; stability parameters; biofortification

\section{Introduction}

Lentil (Lens culinaris Medikus ssp. culinaris) grains are enriched with abundant protein, prebiotic carbohydrates, vitamins, macro- and micro-nutrients [1,2]. Lentil grains provide quality protein with significant concentration of endogenous amino acids viz. leucine, arginine, glutamic and aspartic acids [3]. Globally lentil is cultivated on over 4.8 Mha with a production of $5.73 \mathrm{M}$ tons [4]. Lentil is the fifth most important grain legume grown in around 50 countries. Recommended daily allowance (RDA) for iron is $8.0 \mathrm{mg}$ and 18.0 $\mathrm{mg}$, while for zinc it is $11.0 \mathrm{mg}$ and $8.0 \mathrm{mg}$ for males and females, respectively, according to the National Institute of Health (NIH). Daily consumption of $100 \mathrm{~g}$ of lentil grains can provide a considerable amount of RDA for iron and zinc [5,6]. In many of the developing 
countries lentil supplements cereals in daily diets of the resource-poor populations [7]. Being an ample source of iron ( $\mathrm{Fe}$ ) and zinc $(\mathrm{Zn})$ and grown in micronutrient-deficient and resource-poor areas, lentil is a candidate crop for micronutrient biofortification [8].

Micronutrient deficiency persists as a serious global health concern affecting more than one fourth of the world's population [9]. Among micronutrient deficiencies, $\mathrm{Fe}$ and $\mathrm{Zn}$ deficiencies are the major manifestations of mineral malnutrition. Fe is integral to oxygen transport proteins, viz. hemoglobin and myoglobin [10]. Fe deficiency is the predominant cause of anemia, affecting $27 \%$ of global population [11]. Fe deficiency and anemia lead to impaired cognitive development, immune suppression, fatigue, low-birth weight of infants, increased mortality and morbidity [12,13]. About $17-29.6 \%$ of the global population is estimated to be at risk of low zinc intake with high prevalence in South Asia, South-East Asia, Sub-Saharan Africa and Central America [14]. High mortality rate has been reported among children resulting from infections associated with inadequate $\mathrm{Zn}$ intake. $\mathrm{Zn}$ performs major roles in biological systems as a catalyst, structural and regulatory ion [15]. $\mathrm{Zn}$ is involved in several metabolic pathways and hence is a key component in normal body growth and development. Zn deficiency causes delayed and reduced growth, hypogonadism, epidermal disorders and dysfunction of immune and central nervous systems [16]. Regular intake of $\mathrm{Zn}$ is required to avoid $\mathrm{Zn}$ deficiency as this micronutrient cannot be stored in the human body $[15,16]$.

Agronomic fortification, post-harvest food fortification, diversified diet and oral supplementation are possible means to combat micronutrient deficiency but biofortification stands as a relatively feasible, effective, safe and sustainable micronutrient delivery approach. Biofortification, a conventional or molecular breeding-based approach, can enrich food crops nutritionally with enhanced bioavailability [17]. In order to breed micronutrient dense cultivars, substantial genetic variation in the gene pool for grain $\mathrm{Fe}$ and $\mathrm{Zn}$ concentration is a prerequisite.

Lentil germplasm evaluation [18-20] has revealed wide variation for grain Fe and $\mathrm{Zn}$ concentrations. The inheritance of grain micronutrient concentration is complex with high environmental influence [6]. Genotypes expressing stable performance across environments for micronutrient concentrations can be utilized for breeding biofortified lentil varieties. Genotype by Environment Interactions (GEI) for complex traits can be dissected using statistical tools such as analysis of variance, whereas different statistical models, including univariate and multivariate, can facilitate identification of stable genotypes [21]. Additive main effects and multiplicative interaction (AMMI) model and the genotype main effects plus the $\mathrm{G} \times \mathrm{E}$ (GGE) model are the most conventionally followed multivariate statistical models for determining genotypic stability from multi-location trial data. While the AMMI model helps in understanding the structure of GEI in addition to estimating the total deviation of interaction and differentiating the main interactions from each another [22,23], the GGE model helps in determining wining genotypes suited to different environments and ranking them in tested environments based on their performances. The aim of the present investigation was to evaluate genetic diversity and decipher genotype by environment interaction effect among Indian and Mediterranean lentil genotypes for grain micronutrient concentrations for identification of $\mathrm{Fe}$ and $\mathrm{Zn}$ rich stable genotypes.

\section{Materials and Methods}

\subsection{Plant Material and Field Experimentation}

Grain iron and zinc concentrations were evaluated in a set of ninety-six lentil genotypes. The studied genotypes comprised of Indian (released varieties, advanced breeding lines, germplasm lines) as well as Mediterranean (landraces and ICARDA germplasm) genotypes (Table 1). The genotypes were raised at three locations: (i) Experimental Farm, Division of Genetics, Indian Agricultural Research Institute, New Delhi $\left(28^{\circ} 38^{\prime} 23^{\prime \prime} \mathrm{N}\right.$, $77^{\circ} 09^{\prime} 27^{\prime \prime}$ E, $228 \mathrm{~m}$ above mean sea level); (ii) Jawaharlal Nehru Krishi Vishwa Vidyalaya, Sagar $\left(30.9^{\circ} \mathrm{N}, 75.85^{\circ} \mathrm{E}, 244 \mathrm{~m}\right.$ amsl); and (iii) RAK, Sehore $\left(23.06^{\circ} \mathrm{N}, 77.05^{\circ} \mathrm{E}, 498.77 \mathrm{~m}\right.$ amsl) during the winter season of 2016-17 following the standard package of practices. 
Entries were planted in randomized block designs in three rows of five-meter length with two replications and inter-row spacing of $25 \mathrm{~cm}$, plant to plant spacing of $5 \mathrm{~cm}$.

Table 1. Genotypes used and their source.

\begin{tabular}{|c|c|c|c|}
\hline S.No. & Genotype & Type of Genotype & Source \\
\hline $1-13$ & $\begin{array}{l}\text { IC 201704, IC 208326, IC 262839, IC 267663, IC 268248, IC } \\
\text { 560135, IC 560169, IC 560181, IC 560206, IC 560212, IC 560333, } \\
\text { IC 560372, IC 560812 }\end{array}$ & $\begin{array}{l}\text { Indian } \\
\text { germplasm lines }\end{array}$ & $\begin{array}{l}\text { NBPGR, } \\
\text { New Delhi, India }\end{array}$ \\
\hline $14-38$ & $\begin{array}{l}\text { IG 111996, IG 112078, IG 112128, IG 112131, IG 115, IG 129214, } \\
\text { IG 129291, IG 129302, IG 129304, IG 129317, IG 130033, IG 195, } \\
\text { IG 49, IG 5320, IG 569608, IG 70230, IG 73798, IG 73920, IG } \\
\text { 73933, IG 9, ILL 10832, ILL 108331, ILL 147, ILL 2581, ILL } 7663\end{array}$ & Mediterranean landraces & ICARDA, Aleppo, Syria \\
\hline $39-46$ & $\begin{array}{l}\text { L 11-243, L 11-273, L 11-279, L 11-282, L 11-289, L 11-291, L } \\
\text { 11-294, L 11-297 }\end{array}$ & $\begin{array}{c}\text { Advanced } \\
\text { breeding lines }\end{array}$ & $\begin{array}{l}\text { AICRP MULLaRP, IIPR, } \\
\text { Kanpur India }\end{array}$ \\
\hline 47 & L 4076 & $\begin{array}{l}\text { Released } \\
\text { variety }\end{array}$ & IARI, New Delhi, India \\
\hline $48-61$ & $\begin{array}{l}\text { L 5253, L 7818, L 7903, L 7916, L 7920, LC 282-1444, LC 282-1485, } \\
\text { LC 282896, LC 282907, } \\
\text { LC 300-15, LC 300-16, LC 300-17, LC 300-19, LC 74151 }\end{array}$ & $\begin{array}{l}\text { Advanced } \\
\text { breeding lines }\end{array}$ & IARI, New Delhi, India \\
\hline 62 & LH 90-57 & Advanced breeding lines & CCS, HAU, Hisar, India \\
\hline $63-66$ & LL 1122, LL 147, LL 461, LL 649 & $\begin{array}{c}\text { Advanced } \\
\text { breeding lines }\end{array}$ & PAU, Ludhiana, India \\
\hline $67-85$ & $\begin{array}{l}\text { P 13108, P 13129, P 13135, P 13138, P 13142, P 13143, P 15104, } \\
\text { P 15121, P 15127, P 16214, P 2113, P 2116, P 2118, P 2125, P 2127, } \\
\text { P 3233, P 3234, P 8112, P } 8115\end{array}$ & $\begin{array}{l}\text { ICARDA } \\
\text { Nursery } \\
\text { selection }\end{array}$ & $\begin{array}{l}\text { ICARDA, Aleppo, } \\
\text { ICARDA, Aleppo, Syria }\end{array}$ \\
\hline $86-92$ & PL 02, PL 04, PL 05, PL 06, PL 07, PL 08, PL 406 & $\begin{array}{l}\text { Released } \\
\text { varieties }\end{array}$ & $\begin{array}{l}\text { GBPUAT, Pantnagar, } \\
\text { India }\end{array}$ \\
\hline $93-96$ & PL 117, PL 24, PL 77-12, PL 97 & $\begin{array}{c}\text { Advanced } \\
\text { breeding lines }\end{array}$ & $\begin{array}{l}\text { GBPUAT, Pantnagar, } \\
\text { India }\end{array}$ \\
\hline
\end{tabular}

\subsection{Grain Iron and Zinc Analysis}

Grains were harvested at physiological maturity and dried to less than $12 \%$ moisture content in dust-free conditions to avoid soil contamination. Grains were sorted manually to discard damaged and immature grains and stored in clean containers. For micronutrient analysis the grains were washed with Milli-Q water to remove the dust and oven dried at $35^{\circ} \mathrm{C}$ for 5 days. Three grams of grains were grounded into fine powder using mortar and pestle manually. Powdered samples $(0.5 \mathrm{~g})$ were digested as per modified diacid protocol by Singh et al. [24] using a microwave digestion system (Multiwave ECO, Anton Paar, les Ulis, France). Iron and zinc concentrations (in ppm) were measured using atomic absorption spectrometry (Zeeman AAS, Z-Xpress 8000, Jena, Germany).

\subsection{Statistical Analysis}

Combined analysis of variance (ANOVA) across environments was performed following homogeneity test of error variance based on Bartlett's test. Stability analysis was carried out using AMMI and genotype plus genotype $\times$ environment (GGE) models. AMMI1 biplot was graphed using means of the main effect vs. first interaction principal component (IPC1) score, as per Zobel et al. [25]. Modified AMMI stability index (MASI) and Modified AMMI stability value (MASV) were computed for grain iron and zinc concentrations as per Ajay et al. $[26,27]$ as follows: 
MASI was calculated as per Ajay et al. [26]:

$$
\operatorname{MASI}=\underset{\mathrm{n}=1}{\sqrt{ }\left(\sum^{\prime} \mathrm{PCn}^{2} \times \theta \mathrm{n}^{2}\right)}
$$

MASV was calculated for studied nutritional traits according to Ajay et al. [27] as follows:

$$
\begin{aligned}
& N^{\prime}-1 \\
& \mathrm{MASV}= \sqrt{ } \sum(\mathrm{SSIPCn} / \mathrm{SSIPC} \mathrm{n}+1 \times \mathrm{PCn})^{2}+\left(\mathrm{PC}_{\mathrm{N}^{\prime}}\right)^{2} \\
& \mathrm{n}=1
\end{aligned}
$$

where $\mathrm{SSIPC}_{1}, \mathrm{SSIPC}_{2}, \mathrm{SSIPC}_{\mathrm{n}}$ denote the sum of squares of 1st, 2nd and nth IPCs; PC $\mathrm{PC}_{2}, \ldots \mathrm{PC}_{\mathrm{n}}$ denote the scores of $1 \mathrm{st}, 2 \mathrm{nd}$ and nth IPCs; $\theta_{\mathrm{n}}$ is the percentage sum of squares explained by the nth principal component interaction effect and $N^{\prime}$ denotes the number of significant IPCs retained by the AMMI model. Lower MASI and MASV scores denote stability of genotypes across environments.

Simultaneous selection index for trait mean performance and stability was calculated using the genotype selection index approach suggested by Farshadfar et al. [28]:

$$
\mathrm{GSI}=\mathrm{RMASI}+\mathrm{R}
$$

where RMASI is the ranking of the modified AMMI stability index and R is the ranking of the traits in all environments.

In addition, 'which-won-where' /GGE Biplots were plotted taking IPCA1 on $x$-axis and IPCA2 on $y$-axis as per Yan and Kang [29]. Data analysis was performed using software R (version 4.0.5; The R Foundation for Statistical Computing Platform, Vienna, Austria). The GGE biplot was graphed using GGEbiplotGUI package tool of the R software.

\section{Results}

\subsection{Mean Performance of Genotypes}

Mean performance and descriptive statistics of ninety-six genotypes evaluated across three locations are presented in Table 2. A wider array of variation was exhibited for studied traits in different environments. Genotypes constituting the panel followed normal distribution for grain $\mathrm{Fe}$ and $\mathrm{Zn}$ concentration (Figure 1). Analysis of variance indicated that the panel of lentil genotypes differed significantly $(p \leq 0.01)$ among themselves for grain $\mathrm{Fe}$ and $\mathrm{Zn}$ concentrations across locations (Table 3). Mean grain Fe and $\mathrm{Zn}$ concentration over all locations and genotypes sampled was $70.46 \mathrm{mg} / \mathrm{kg}$ and $56.83 \mathrm{mg} / \mathrm{kg}$, with genotypic mean Fe and Zn concentration ranging from 39.38 to $105.41 \mathrm{mg} / \mathrm{kg}$ and 27.4 to $87.3 \mathrm{mg} / \mathrm{kg}$, respectively (Table 2). Genotypes P $16214(105.41 \mathrm{mg} / \mathrm{kg})$ followed by IG $115(96.51 \mathrm{mg} / \mathrm{kg})$, P $2127(96.42 \mathrm{mg} / \mathrm{kg})$ and IC $560812(95.14 \mathrm{mg} / \mathrm{kg})$ had the highest mean grain Fe concentrations while genotypes P $8115(87.3 \mathrm{mg} / \mathrm{kg})$, P $3234(79.9 \mathrm{mg} / \mathrm{kg}), \mathrm{LL} 461(79.85 \mathrm{mg} / \mathrm{kg})$ and IC $560812(79.1 \mathrm{mg} / \mathrm{kg})$ exhibited the highest mean grain Zn concentrations (Table 4). Mean performances for Fe and $\mathrm{Zn}$ concentrations were relatively higher at the Sehore location, while mean performances for both the traits were low at the Delhi location (Tables 2 and S1). No correlation was observed between grain Fe and $\mathrm{Zn}$ concentration. Similar results have been previously observed in lentil [6,19]. 
Table 2. Descriptive statistics of ninety-six lentil genotypes for grain iron and zinc concentrations across three locations.

\begin{tabular}{|c|c|c|c|c|c|c|c|}
\hline Variable & Locations & Mean & SD & SE & $\mathrm{CV}$ & Minimum & Maximum \\
\hline \multirow{4}{*}{$\begin{array}{c}\mathrm{Fe} \\
(\mathrm{mg} / \mathrm{kg})\end{array}$} & Delhi & 68.97 & 13.82 & 1.41 & 20.04 & 37.7 & 116.75 \\
\hline & Sagar & 69.85 & 14.18 & 1.45 & 20.30 & 38.95 & 106.73 \\
\hline & Sehore & 72.55 & 15.78 & 1.61 & 21.75 & 34.4 & 107.26 \\
\hline & Combined locations & 70.46 & 13.00 & 1.33 & 18.45 & 39.38 & 105.41 \\
\hline \multirow{4}{*}{$\begin{array}{c}\mathrm{Zn} \\
(\mathrm{mg} / \mathrm{kg})\end{array}$} & Delhi & 55.90 & 12.87 & 1.31 & 23.02 & 24.3 & 87 \\
\hline & Sagar & 57.05 & 13.26 & 1.35 & 23.24 & 27.45 & 94.45 \\
\hline & Sehore & 57.51 & 13.30 & 1.36 & 23.13 & 30.35 & 87.7 \\
\hline & Combined locations & 56.83 & 11.92 & 1.22 & 20.97 & 27.4 & 87.3 \\
\hline
\end{tabular}
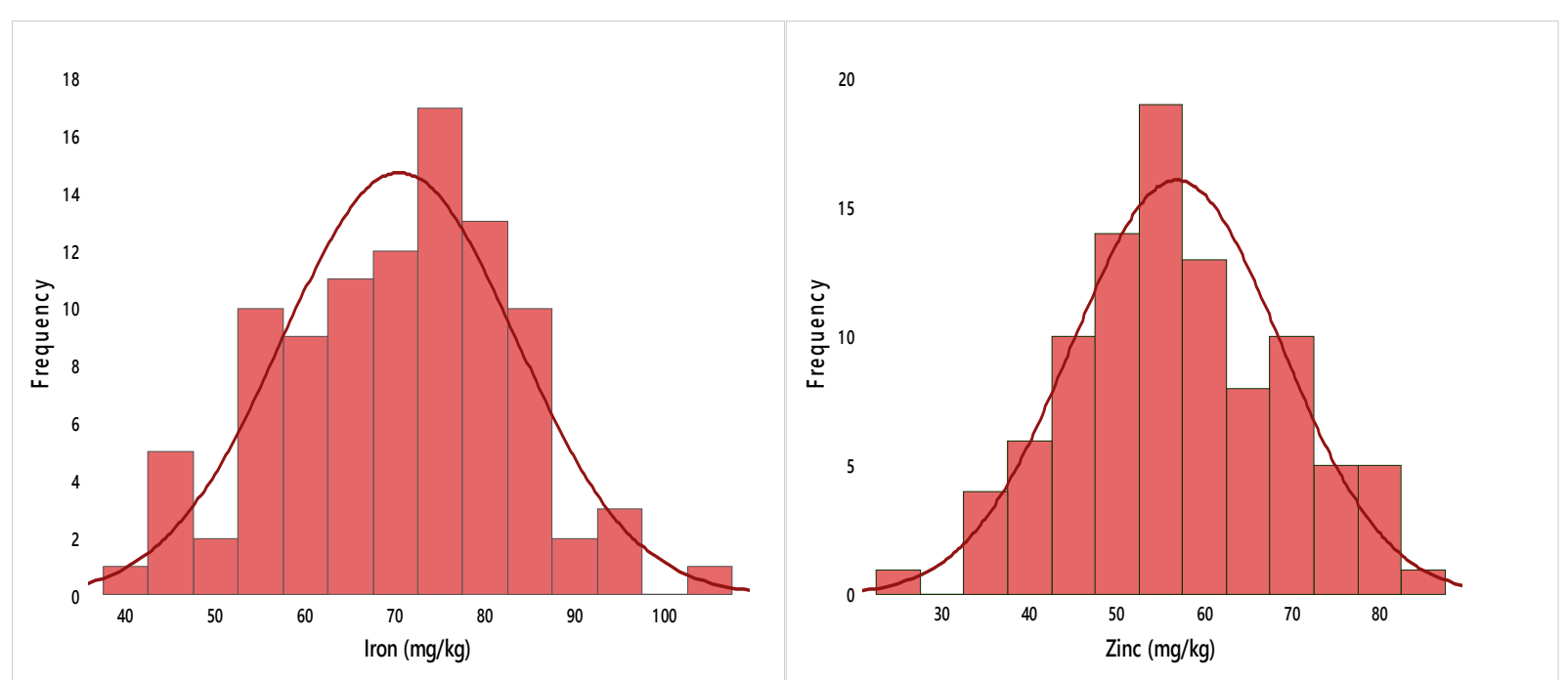

Figure 1. Frequency distribution of ninety-six lentil genotypes for grain iron and zinc concentration pooled across three locations.

Table 3. Mean sum of squares for grain iron and zinc concentrations obtained by pooled ANOVA across three locations for ninety-six lentil genotypes.

\begin{tabular}{cccc}
\hline \multirow{2}{*}{ Source } & \multirow{2}{*}{ DF } & \multicolumn{2}{c}{ Mean Sum of Squares } \\
\cline { 3 - 4 } & & Iron & Zinc \\
\hline Genotype $(\mathrm{G})$ & 95 & $1014.02^{* *}$ & $851.84^{* *}$ \\
\hline Environment $(\mathrm{E})$ & 2 & $668.06^{*}$ & $131.74^{*}$ \\
\hline Genotype $\times$ Environment $(\mathrm{G} \times \mathrm{E})$ & 190 & $134.2^{* *}$ & $92.46^{* *}$ \\
\hline Replication within Environment & 3 & 3.784 & 9.29 \\
\hline IPCA1 & 96 & $156.23^{* *}$ & $111.05^{* *}$ \\
\hline IPCA2 & 94 & $123.70^{* *}$ & $107.81^{* *}$ \\
\hline Total & 575 & 1832.29 & 1091.27 \\
\hline
\end{tabular}

Significance * and ${ }^{* *}$ significant at, $p<0.05$ and $p<0.01$. 
Table 4. Mean grain iron and zinc concentrations, genotype ranking, modified AMMI stability values (MASV), modified AMMI stability indices (MASI), rank orders (rank MASV / MASI) and genotypic selection index (GSI) of 41 high iron and zinc genotypes tested across three locations.

\begin{tabular}{|c|c|c|c|c|c|c|c|c|c|c|c|c|c|}
\hline $\begin{array}{l}\text { S. } \\
\text { No. }\end{array}$ & Genotype & $\begin{array}{l}\text { Mean Fe } \\
(\mathrm{mg} / \mathrm{kg})\end{array}$ & $\operatorname{Rank}_{\mathrm{Fe}}$ & MASV $_{\mathrm{Fe}}$ & MASI $_{\mathrm{Fe}}$ & $\begin{array}{c}\text { Rank } \\
\text { MASV }_{\mathrm{Fe}} / \\
\text { MASI }_{\mathrm{Fe}}\end{array}$ & $\mathrm{GSI}_{\mathrm{Fe}}$ & $\underset{(\mathrm{mg} / \mathrm{kg})}{\operatorname{Mean} \mathrm{Zn}}$ & Rank $_{\mathrm{Zn}}$ & MASV $_{\mathrm{Zn}}$ & MASI $_{\mathrm{Zn}}$ & $\begin{array}{c}\text { Rank } \\
\text { MASV }_{\mathrm{Zn}} / \\
\text { MASI }_{\mathrm{Zn}}\end{array}$ & $\mathrm{GSI}_{\mathrm{Zn}}$ \\
\hline 1 & L 4076 & 76.84 & 14 & 2.84 & 1.25 & 40 & 54 & 70.41 & 12 & 1.40 & 0.69 & 21 & 33 \\
\hline 2 & ILL 7663 & 61.56 & 36 & 1.63 & 0.72 & 20 & 56 & 67.80 & 16 & 1.93 & 0.95 & 38 & 54 \\
\hline 3 & Р 3234 & 77.26 & 12 & 1.60 & 0.70 & 19 & 31 & 79.91 & 2 & 1.38 & 0.68 & 17 & 19 \\
\hline 4 & Р 2116 & 75.29 & 15 & 1.89 & 0.83 & 26 & 41 & 64.71 & 18 & 1.35 & 0.66 & 15 & 33 \\
\hline 5 & L 11-289 & 60.77 & 41 & 2.28 & 1.00 & 37 & 78 & 60.80 & 26 & 2.30 & 1.13 & 41 & 67 \\
\hline 6 & IC 560333 & 78.52 & 10 & 1.47 & 0.65 & 12 & 22 & 56.50 & 35 & 1.57 & 0.77 & 26 & 61 \\
\hline 7 & PL 77-12 & 65.98 & 32 & 2.06 & 0.91 & 30 & 62 & 65.41 & 17 & 1.64 & 0.80 & 29 & 46 \\
\hline 8 & L 7916 & 69.48 & 25 & 1.59 & 0.70 & 17 & 42 & 61.01 & 25 & 1.14 & 0.56 & 4 & 29 \\
\hline 9 & PL 04 & 77.11 & 13 & 1.50 & 0.66 & 14 & 27 & 68.27 & 15 & 1.19 & 0.58 & 5 & 20 \\
\hline 10 & LL 1122 & 80.61 & 9 & 2.03 & 0.89 & 28 & 37 & 73.98 & 8 & 1.91 & 0.94 & 37 & 45 \\
\hline 11 & LC 282-907 & 67.21 & 29 & 1.56 & 0.69 & 15 & 44 & 62.01 & 22 & 1.97 & 0.97 & 39 & 61 \\
\hline 12 & IC 208326 & 88.05 & 5 & 2.05 & 0.90 & 29 & 34 & 62.58 & 21 & 1.39 & 0.68 & 18 & 39 \\
\hline 13 & P 15121 & 61.27 & 38 & 1.05 & 0.47 & 1 & 39 & 55.68 & 39 & 1.40 & 0.68 & 20 & 59 \\
\hline 14 & P 16214 & 105.41 & 1 & 3.24 & 1.42 & 41 & 42 & 73.35 & 9 & 1.21 & 0.59 & 7 & 16 \\
\hline 15 & PL 02 & 60.82 & 40 & 2.30 & 1.01 & 38 & 78 & 63.35 & 20 & 1.78 & 0.87 & 33 & 53 \\
\hline 16 & IG 115 & 96.51 & 2 & 1.91 & 0.84 & 27 & 29 & 59.63 & 29 & 1.80 & 0.88 & 34 & 63 \\
\hline 17 & L 7903 & 63.72 & 35 & 1.36 & 0.60 & 9 & 44 & 53.63 & 41 & 1.90 & 0.93 & 36 & 77 \\
\hline 18 & LH 90-57 & 81.76 & 7 & 1.76 & 0.77 & 23 & 30 & 60.00 & 28 & 1.52 & 0.75 & 25 & 53 \\
\hline 19 & LL 461 & 66.79 & 31 & 2.24 & 0.98 & 35 & 66 & 79.85 & 3 & 1.68 & 0.82 & 31 & 34 \\
\hline 20 & PL 05 & 81.14 & 8 & 2.26 & 0.99 & 36 & 44 & 56.30 & 37 & 1.28 & 0.63 & 12 & 49 \\
\hline 21 & P 2118 & 65.34 & 33 & 1.09 & 0.48 & 2 & 35 & 73.25 & 10 & 1.22 & 0.60 & 9 & 19 \\
\hline 22 & IC 560812 & 95.14 & 3 & 2.19 & 0.96 & 34 & 37 & 79.06 & 4 & 1.76 & 0.86 & 32 & 36 \\
\hline 23 & IC 560206 & 68.79 & 27 & 1.36 & 0.60 & 8 & 35 & 64.31 & 19 & 1.50 & 0.73 & 24 & 43 \\
\hline 24 & Р 2113 & 60.91 & 39 & 1.24 & 0.54 & 4 & 43 & 69.71 & 13 & 1.67 & 0.82 & 30 & 43 \\
\hline 25 & L 11-291 & 71.19 & 23 & 2.18 & 0.96 & 33 & 56 & 56.06 & 38 & 1.31 & 0.64 & 13 & 51 \\
\hline 26 & L 11-294 & 72.59 & 20 & 1.56 & 0.69 & 16 & 36 & 54.15 & 40 & 2.19 & 1.07 & 40 & 80 \\
\hline 27 & IC 262839 & 61.48 & 37 & 2.53 & 1.11 & 39 & 76 & 77.50 & 6 & 1.61 & 0.79 & 27 & 33 \\
\hline 28 & IG 112128 & 73.46 & 19 & 1.49 & 0.65 & 13 & 32 & 61.68 & 23 & 1.33 & 0.65 & 14 & 37 \\
\hline 29 & ILL 147 & 88.36 & 4 & 1.74 & 0.76 & 21 & 25 & 61.03 & 24 & 1.05 & 0.51 & 3 & 27 \\
\hline 30 & LC 74151 & 67.78 & 28 & 2.14 & 0.94 & 32 & 60 & 58.98 & 30 & 1.42 & 0.70 & 22 & 52 \\
\hline 31 & LC 282896 & 74.05 & 17 & 1.31 & 0.57 & 6 & 23 & 77.63 & 5 & 1.46 & 0.71 & 23 & 28 \\
\hline 32 & IG 9 & 82.06 & 6 & 1.81 & 0.80 & 25 & 31 & 60.15 & 27 & 0.99 & 0.48 & 1 & 28 \\
\hline 33 & L 11-282 & 69.37 & 26 & 1.34 & 0.59 & 7 & 33 & 57.66 & 33 & 1.37 & 0.67 & 16 & 49 \\
\hline 34 & LC 300-17 & 73.71 & 18 & 1.79 & 0.79 & 24 & 42 & 69.26 & 14 & 1.26 & 0.62 & 11 & 25 \\
\hline 35 & PL 07 & 70.78 & 24 & 1.31 & 0.57 & 5 & 29 & 58.61 & 31 & 1.03 & 0.50 & 2 & 33 \\
\hline 36 & IG 49 & 77.69 & 11 & 1.37 & 0.60 & 10 & 21 & 58.50 & 32 & 1.22 & 0.60 & 8 & 40 \\
\hline 37 & IC 560135 & 74.15 & 16 & 2.13 & 0.94 & 31 & 47 & 75.05 & 7 & 1.40 & 0.68 & 19 & 26 \\
\hline 38 & LC 282-1485 & 71.44 & 22 & 1.10 & 0.48 & 3 & 25 & 70.90 & 11 & 1.83 & 0.90 & 35 & 46 \\
\hline 39 & P 8115 & 64.34 & 34 & 1.43 & 0.63 & 11 & 45 & 87.26 & 1 & 1.63 & 0.80 & 28 & 29 \\
\hline 40 & P 13142 & 71.49 & 21 & 1.59 & 0.70 & 18 & 39 & 56.98 & 34 & 1.20 & 0.59 & 6 & 40 \\
\hline 41 & P 13143 & 66.96 & 30 & 1.75 & 0.77 & 22 & 52 & 56.36 & 36 & 1.24 & 0.60 & 10 & 46 \\
\hline
\end{tabular}

\subsection{Pooled Analysis of Variance}

Bartlett's test-based homogeneity of variance test indicated homogeneous error variance for both the micronutrients, permitting for pooled ANOVA across environments. Pooled ANOVA of ninety-six lentil genotypes was performed considering locations as random effect and genotypes as fixed effects. Pooled ANOVA revealed highly significant 
GEI $(p<0.001)$. Genotype effects were also highly significant $(p<0.001)$ and environmental effects were significant $(p<0.05)$ (Table 3$)$. The relative magnitudes of genotype, environment and GEI variances to the total sum of square accounted for $76.05 \%, 1.05 \%$ and $20.13 \%$ for grain Fe concentration and $80.54 \%, 0.26 \%$ and $17.48 \%$ for grain Zn concentration, respectively. Percentage share of GEI variances for grain Fe and $\mathrm{Zn}$ concentrations indicates the traits are highly influenced by environmental factors including soil $\mathrm{pH}$, micronutrient status, their availability to plants, etc. Several studies have reported significant effect of GEI for grain Fe and $\mathrm{Zn}$ concentrations in various crops including wheat [30-32], maize [33,34] and pearl millet [35]. Though both the micronutrients exhibited considerable environmental interactions, the magnitude of GEI variances to the total sum of the square indicated greater sensitivity of grain iron concentration to environmental factors than grain zinc concentration. Substantial GEI observed in the study implies difference in response of genotypes across environments. The observed magnitude of genotypic variation suggests it should be possible to improve nutritional qualities of lentils through breeding approaches despite significant GEI.

\subsection{AMMI Aanalysis}

The three sums of squares (SS) from ANOVA, viz. genotype, GE signal and GE noise, indicate appropriateness of AMMI analysis for a given dataset. AMMI analysis is relevant for datasets with considerable GE signal. If SS for GE noise and GEI are nearly equal, then GEI is buried in noise and AMMI analysis is not relevant. To find the relevance of the AMMI analysis, sum of squares GE noise and GE signal were calculated as per Gauch [36]. Sum of squares for genotype and GEI were obtained directly through ANOVA, whereas sum of square for GE noise was estimated by multiplying error mean square by number of degrees of freedom for GEI. GE signal was then obtained by subtracting GE noise from GEI. Sum of squares obtained for GE noise for both Fe (2325.6) and Zn (1126.7) were substantially less than SS for GEI (25,449 for Fe and 17,568 for Zn), indicating outcomes from AMMI analysis are worthwhile.

Stability analysis employing AMMI model elucidated that only the first two interaction principal components, IPC1 and IPC2, were significant based on Gollob's F-test [37] and together explained 100\% of GEI variation with no residual left. IPC1 and IPC2 explained $55.9 \%$ and $44.1 \%$ of the total GEI sum of squares for grain Fe concentration, whereas they explained $50.8 \%$ and $49.2 \%$ of the total GEI sum of squares for grain $\mathrm{Zn}$ concentration, respectively. Of the two AMMI biplots, the AMMI1 biplot was plotted between the main effects of trait mean (genotypic and environmental mean) and IPCA1 scores for both genotype and environment, whereas the AMMI2 biplot has been plotted taking scores of IPC1 vs. IPC2. The biplots were constructed comprising genotypes having high grain mean Fe (>60 mg/kg) and $\mathrm{Zn}(>53 \mathrm{mg} / \mathrm{kg})$ concentrations for better interpretation and visualization. Hence, forty-one genotypes exhibiting higher mean for both micronutrients were included for plotting AMMI1 and AMMI2 biplots (Table 4). Fifteen genotypes showed above-average performance for grain Fe concentration in the AMMI1 biplot between mean grain Fe concentration vs. IPCA1 of GEI (Figure 2a). Out of fifteen genotypes, only two genotypes IC 560812 (G22) and IG 49 (G36) were found having higher mean Fe concentration while lying closer to the origin/lower IPCA1 score (Figure 2a). These two genotypes had adaptability across locations based on their IPCA1 scores. Similarly, sixteen genotypes showed above-average performance for grain $\mathrm{Zn}$ concentration in AMMI1 biplot. Among these sixteen genotypes, three genotypes, IC 262839 (G27), P 16214 (G14) and P 2113 (G24), were the most adapted across locations, having higher mean $\mathrm{Zn}$ concentration (Figure 2c). 


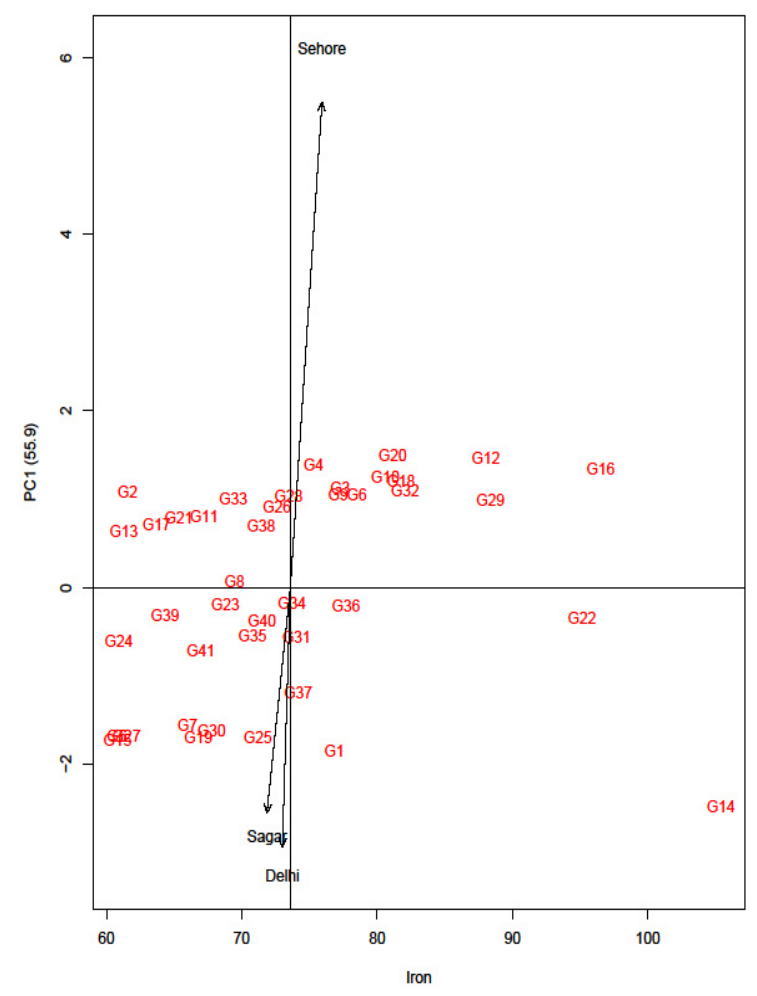

(a)

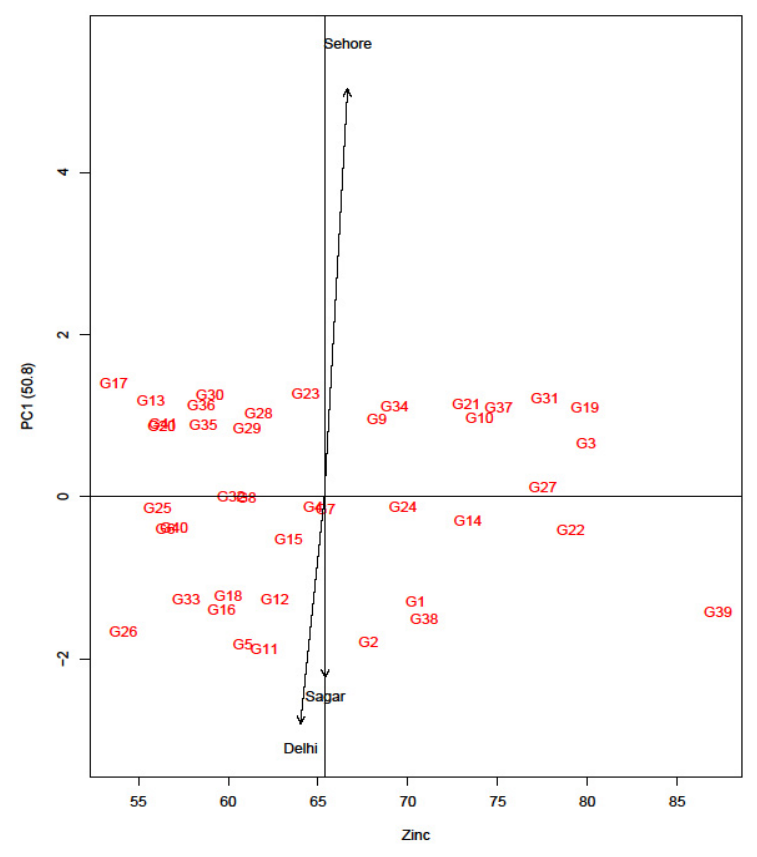

(c)
Which Won Where/What

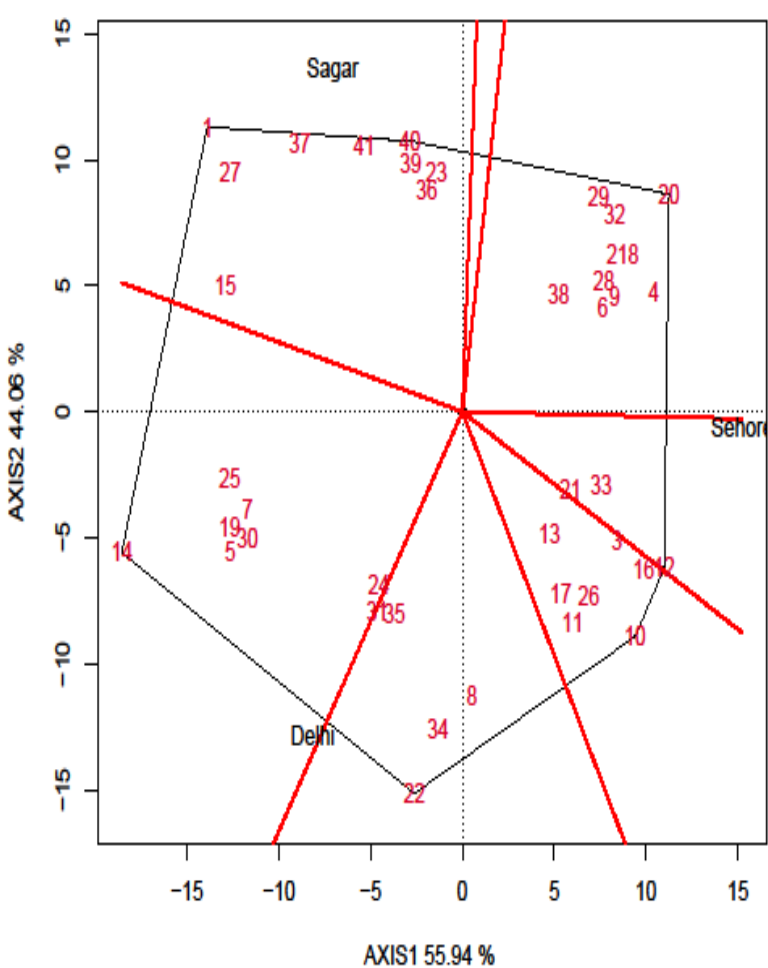

(b)

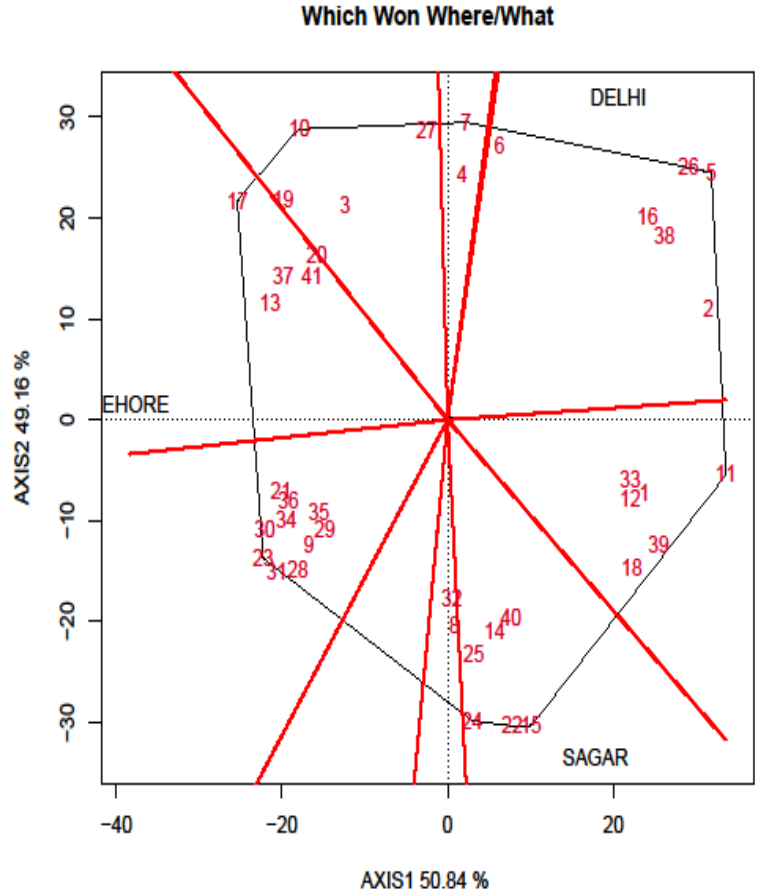

(d)

Figure 2. AMMI1 biplot between mean iron and zinc values over three locations vs. IPC1 and AMMI2/GGE biplot between IPC1 vs. IPC2 (a) AMMI1 biplot for 41 high iron lines, (b) AMMI2/GGE biplot for 41 high iron lines, (c) AMMI1 biplot for 41 high zinc lines, (d) AMMI2/GGE biplot for 41 high zinc lines. 
'Which-won-where' biplot enables identification of stable genotypes, representative environment and best performing genotypes to mega-environments. The AMMI2 biplot plotted between IPCA1 and IPCA2 revealed genotypes specifically adapted to different locations investigated in the study. Genotype P 16214 (G14) performed well in Delhi and L 4076 (G1) in Sagar, whereas IC 208326 (G12) performed well in Sehore for grain Fe concentration (Figure 2b). For grain Zn concentration, L 11-289 (G5) followed by L 11-294 (G26) were specifically adapted to Delhi, PL 02 (G15) followed by IC 560812 (G22) to Sagar and L 7903 (G17) had specific adaptation to Sehore (Figure 2d).

\subsection{Stability Analysis Using MASI and GSI}

The AMMI model, as a measure of stability, does not furnish stability quantitatively. To rectify the problem, Purchase [38] and Purchase et al. [39] proposed the AMMI stability value (ASV) to quantify and rank genotypes, which is required for facilitating genotypic selection. Later, Zali et al. [40] developed modified ASV (MASV), incorporating the relative weight of all significant IPCAs to compute stability measure. Retaining all significant IPCA axes improves reliability of stability measure providing more comprehensive and precise information. Recently, Ajay et al. [27] rectified the existing MASV by Zali et al. [40] and proposed a new corrected formula for MASV as MASV2, which significantly improved ranking of genotypes. Ranking of genotypes based on both MASV and MASI values indicated P 15121 (G13), P 2118 (G 21) and LC 282-1485 (G38) had the lowest MASV and MASI values and hence were the most stable lines for grain Fe concentration. Similarly, genotypes IG 9 (G32) followed by PL 07 (G35) and ILL 147 (G29) were identified as stable lines for grain Zn concentration. PL 07 (G35), P 2118 (G21) and IG 49 (G36) had relatively low MASV and MASI values for both the micronutrients. Selection of genotypes cannot be made considering stability per se as the most stable lines may not be the best performer and vice versa. Hence, both mean and stability of performance should be simultaneously considered for selection of genotypes to be effective and precise. GSI, a simultaneous selection index approach for trait mean performance and stability, was employed where the lowest GSI implies stability of line along with high mean performance. In the study, genotypes IG 49 (G36), IC 560333 (G6), LC 282896 (G31), ILL 147 (G29) and IG 115 (G16) scored lowest in GSI for grain Fe, while genotypes P 16214 (G14), P 2118 (G21), PL 04 (G9), LC 300-17 (G34) and IC 560135 (G37) had the lowest GSI for grain Zn concentration. Genotypes IG 49 (G36), P 16214 (G14), ILL 147 (G29) and P 2118 (G21) were identified as promising stable lines considering the mean Fe and Zn performances, AMMI1 biplot, MASV /MASI and GSI.

\section{Discussion}

Breeding for grain $\mathrm{Fe}$ and $\mathrm{Zn}$ is challenging, owing to polygenic inheritance and environmental influence on the target traits. Identification of stable genotypes through multi-location evaluation is integral for varietal development and release. The present study was conducted to evaluate the genetic variability for grain Fe and $\mathrm{Zn}$ concentrations among diverse lentil genotypes while simultaneously deciphering environmental influence on the studied traits. Mean performance for grain micronutrients at different environments indicated a wide array of variation among genotypes which can be harnessed by including them in breeding programs aiming towards micronutrient enrichment. High genetic variability has been reported in the lentil gene pool for grain micronutrient concentration $[6,18,20,41,42]$. Greater magnitude of genetic variability for grain iron and zinc is pivotal for biofortification breeding and to achieve significant genetic gain through conventional/molecular breeding, provided the trait has high heritability per se [43]. As per this investigation, daily consumption of $100 \mathrm{~g}$ of lentil can potentially meet RDA of iron and zinc depending on the bioavailability of minerals post-consumption.

ANOVA revealed significant genotypic effect for both the traits studied in each sampled environment. ANOVA indicated significant GEI along with environmental effects on grain micronutrient concentrations, which indicated genotypic performance is influenced 
in different environments. Genotype by environment interaction influences micronutrient concentrations by affecting their uptake by roots, translocation through shoots and assimilation in grains [41]. Many researchers have documented significant effect of GEI for grain Fe and $\mathrm{Zn}$ concentrations in various crops including wheat [30-32], maize [34], sorghum [43], pearl millet [35,44] and lentil [45]. The high magnitude of genotypic effect implies hereditary factors do govern these traits but the presence of GEI and the environmental effect led differential responses of genotypes across environments. Kumar et al. [6] reported significant genotype $\times$ year interactions for $\mathrm{Fe}$ and $\mathrm{Zn}$ concentration in lentil, indicating the influence of rainfall, temperature and soil parameters. The percentage share of GEI for grain iron and zinc concentrations indicated both the micronutrients exhibited considerable environmental interactions, though Fe concentration had greater sensitivity towards environmental factors. A similar study in maize by Chakraborti et al. [33] and Agrawal et al. [34] reported kernel Fe to be more greatly influenced by environmental conditions than $\mathrm{Zn}$ concentration, whereas Kumar [46] observed both the micronutrients in lentil to be equally sensitive. The outcomes clearly illustrate those genetics as well as environmental factors determine the micronutrient profile in lentil grains. Hence, both should be given due consideration in selection of superior genotypes and varietal development.

GGE biplot help in identifying genotypes suitable to different environments, interpreting representativeness of test environment and ranking genotypes in tested environments based on their performance. GGE biplot for grain Fe and Zn concentrations formed a polygon with best performing genotypes at the vertices (Figure 2b,d). Different environments had different winning genotypes, indicating crossover genotype by environment interaction. This agrees with previous reports on grain micronutrient concentration assessment in rice [21], pearl millet [35] and sorghum [43].

Of the several stability measures, AMMI stability value (ASV) proposed by Purchase et al. [39,47] is the most popular. ASV considers only the first two IPCs for computation, whereas the MASV considers all the significant IPCs for computation [27]. Unlike ASI, MASI calculates stability value considering all significant IPCs in the AMMI model [26]. In the study, two stability measures, viz. MASV and MASI, were employed. As only IPCA1 and IPCA2 together explained $100 \%$ variability, MASV and MASI measures of the AMMI model became equivalent to drawing a conclusion based on ASV and ASI. Results obtained by MASI and MASV were consistent, indicating the accuracy and usefulness of different methods in deciphering GEI for complex traits and identifying stable genotypes. In the present study, P 15121, P 2118 and LC 282-1485 were identified as the most stable genotypes for grain Fe, while IG 9, PL 07 and ILL 147 were stable for grain Zn concentration. The results are in accordance with studies on stability analysis applying ASV $[35,48]$ and MASV parameters of AMMI model [49,50].

The GSI approach was used for selection of desirable genotypes employing trait mean performance and stability across tested environments simultaneously. Low GSI value indicates high trait mean and stable performance. In the present study, genotypes IG 49, P 16214, ILL 147 and P 2118 were promising stable lines, having higher mean Fe and Zn concentrations based on AMMI1 biplot, MASV/MASI and GSI analysis. These lines could be further tested for their ability to combine for yield and grain micronutrient concentrations for developing stably performing superior and mineral rich lentil varieties.

\section{Conclusions}

The indigenous and exotic lentil lines investigated in this study exhibited wide variability for grain micronutrient concentrations which can be tapped by including them in breeding programs for micronutrient alleviation. Genetic variation for investigated micronutrients can be utilized for mapping genes/quantitative trait loci (QTL) governing iron and zinc uptake and accumulation in grains. Stability analysis revealed genotypes IG 49, P 16214, ILL 147 and P 2118 were high performing, promising and stable exotic lines for grain micronutrient concentration which can be used as donors in lentil biofortification breeding for developing nutrient-dense cultivars. These exotic lines can be hybridized 
with indigenous lines to broaden their genetic base while breeding for high micronutrient concentration simultaneously. The genotypes with high Fe (P 16214, IG 115, P 2127 and IC 560812) and Zn (P 8115, P 3234, LL 461 and IC 560812) can be used for developing the mapping populations for deciphering the mode of inheritance of these traits. As no correlation was observed between grain iron and zinc concentrations, high iron and zinc containing lentil lines may be crossed to get recombinants for these micronutrients.

Supplementary Materials: The following are available online at https: / www.mdpi.com/article / 10.3390/agronomy11091761/s1, Table S1: Mean performance (grain Fe and Zn concentration) of studied genotypes over three location.

Author Contributions: Conceptualization, H.K.D.; Methodology, S.G., H.K.D.; Investigation, S.G., A.B., K.T., M.S.A.; Resources, H.K.D., G.P.M., S.K.; Writing-Original draft, S.G., R.B., H.K.D.; Writing-Review and editing, S.D., G.P.M., H.K.D., S.K.; Supervision, H.K.D.; Project administration, H.K.D., G.P.M. All authors have read and agreed to the published version of the manuscript.

Funding: The work was supported and funded by Indian Council of Agricultural Research (ICAR) and CGIAR Program on Grain Legumes and Dryland Agriculture (GLDC) funded by CGIAR fund donors.

Institutional Review Board Statement: Not applicable.

Informed Consent Statement: Not applicable.

Data Availability Statement: Data sharing not applicable.

Acknowledgments: First author acknowledges Council of Scientific and Industrial Research- University Grant Commission (CSIR-UGC) for providing Junior Research Fellowship to pursue Ph.D. Support from Head, Division of Genetics and Joint Director Research IARI, New Delhi is duly acknowledged by all authors. Mediterranean lentil genotypes were provided by ICARDA.

Conflicts of Interest: The authors declare no conflict of interest.

\section{References}

1. Taleb, M.H.; Khodambashi, M.; Karimi, M. Study of physical and nutritional quality properties in segregating generations of lentil cross. Int. J. Agric. Crop Sci. 2013, 5, 2740-2742.

2. Gupta, S.; Singh, A.; Dikshit, H.K.; Aski, M.; Mishra, G.P.; Kumar, J. Assessment of total phenol content, total flavonoid content and anti-oxidant capacity in exotic lentil germplasm. Chem. Sci. Rev. Lett. 2018, 7, 459-463.

3. Khazaei, H.; Subedi, M.; Nickerson, M.; Martínez-Villaluenga, C.; Frias, J.; Vandenberg, A. Seed protein of lentils: Current status, progress, and food applications. Foods 2019, 8, 391. [CrossRef]

4. FAOSTAT. Available online: http:/ / www.fao.org/faostat/en/\#data/QC (accessed on 5 June 2021).

5. Thavarajah, D.; Thavarajah, P.; Sarker, A.; Vandenberg, A. Lentils (Lens culinaris Medikus subspecies culinaris): A whole food for increased iron and zinc intake. J. Agric. Food Chem. 2009, 57, 5413-5419. [CrossRef] [PubMed]

6. Kumar, J.; Thavarajah, D.; Kumar, S.; Sarker, A.; Singh, N.P. Analysis of genetic variability and genotype $\times$ environment interactions for iron and zinc content among diverse genotypes of lentil. J. Food Sci. Technol. 2018, 55, 3592-3605. [CrossRef] [PubMed]

7. Ozer, S.; Karakoy, T.; Toklu, F.; Baloch, F.S.; Kilian, B.; Ozkan, H. Nutritional and physicochemical variation in Turkish kabuli chickpea (Cicer arietinum L.) landraces. Euphytica 2010, 175, 237-249. [CrossRef]

8. Singh, A.; Sharma, V.; Meena, J.; Gupta, S.; Dikshit, H.K.; Aski, M.; Mishra, G.P.; Sarker, A. Genetic variability for grain iron and zinc concentration in lentil. Chem. Sci. Rev. Lett. 2017, 6, 1327-1332.

9. Gonmei, Z.; Toteja, G.S. Micronutrient status of Indian population. Indian J. Med. Res. 2018, 148, 511-521. [CrossRef] [PubMed]

10. Fava, C.; Piepoli, M.; Villani, G.Q. Heart failure and iron deficiency. J. Ital. Cardiol. 2019, 20, 126-135.

11. Ning, S.; Zeller, M.P. Management of iron deficiency. Hematology 2019, 1, 315-322. [CrossRef]

12. Cappellini, M.D.; Musallam, K.M.; Taher, A.T. Iron deficiency anaemia revisited. J. Intern. Med. 2019, 287, 153-170. [CrossRef]

13. Jamnok, J.; Sanchaisuriya, K.; Sanchaisuriya, P.; Fucharoen, G.; Fucharoen, S.; Ahmed, F. Factors associated with anaemia and iron deficiency among women of reproductive age in Northeast Thailand: A cross-sectional study. BMC Public Health 2020, $20,102$. [CrossRef]

14. Gupta, S.; Brazier, A.K.M.; Lowe, N.M. Zinc deficiency in low- and middle-income countries: Prevalence and approaches for mitigation. J. Hum. Nutri. Diet. 2020, 33, 624-643. [CrossRef]

15. Grüngreiff, K.; Gottstein, T.; Reinhold, D. Zinc deficiency-an independent risk factor in the pathogenesis of haemorrhagic stroke? Nutrients 2020, 12, 3548. [CrossRef]

16. Chasapis, C.T.; Ntoupa, P.A.; Spiliopoulou, C.A.; Stefanodou, M.E. Recent aspects of the effects of zinc on human health. Arch Toxicol. 2020, 94, 1443-1460. [CrossRef] [PubMed] 
17. Garg, M.; Sharma, N.; Sharma, S.; Kapoor, P.; Kumar, A.; Chunduri, V.; Arora, P. Biofortified crops generated by breeding, agronomy, and transgenic approaches are improving lives of millions of people around the world. Front. Nutr. $2018,5,12$. [CrossRef] [PubMed]

18. Thavarajah, D.; Thavarajah, P.; Wejesuriya, A.; Rutzke, M.; Glahn, R.P.; Combs, J.G.F.; Vandenberg, A. The potential of lentil (Lens culinaris L.) as a whole food for increased selenium, iron, and zinc intake: Preliminary results from a 3-year study. Euphytica 2011, 180, 123-128. [CrossRef]

19. Vandemark, G.J.; Grusak, M.A.; McGee, R.J. Mineral concentrations of chickpea and lentil cultivars and breeding lines grown in the U.S. Pacific Northwest. Crop J. 2018, 6, 253-262. [CrossRef]

20. Sen Gupta, D.; Thavarajah, D.; Thavarajah, P.; McGee, R.; Coyne, C.J.; Kumar, S. Lentils (Lens culinaris L.), a rich source of folates. J. Agric. Food Chem. 2013, 61, 7794-7799. [CrossRef]

21. Inabangan-Asilo, M.A.; Swamy, B.P.M.; Amparado, A.F.; Descalsota-Empleo, G.I.L.; Arocena, E.C.; Reinke, R. Stability and G $\times$ E analysis of zinc-biofortified rice genotypes evaluated in diverse environments. Euphytica 2019, 215, 61. [CrossRef]

22. Ebdon, J.S.; Gauch, H.G. Additive main effect and multiplicative interaction analysis of national turf grass performance trials I. Interpretation of genotype x environment interaction. Crop Sci. 2002, 42, 489-496.

23. Ebdon, J.S.; Gauch, H.G. Additive main effect and multiplicative interaction analysis of national turfgrass performance trials II. Cultivar recommendations. Crop Sci. 2002, 42, 497-506. [CrossRef]

24. Singh, D.; Chonkar, P.K.; Dwivedi, B.S. Manual on Soil, Plant and Water Analysis; Westville Publishers: New Delhi, India, 2005.

25. Zobel, R.W.; Wright, M.J.; Gauch, H.G. Statistical analysis of a yield trial. Agron. J. 1988, 80, 388-393. [CrossRef]

26. Ajay, B.C.; Aravind, J.; Fiyaz, A.R. Ammistability: R package for ranking genotypes based on stability parameters derived from AMMI model. Indian J. Genet. Plant Breed. 2019, 79, 460-466. [CrossRef]

27. Ajay, B.C.; Aravind, J.; Fiyaz, A.R.; Kumar, N.; Lal, C.; Gangadhar, K.; Kona, P.; Dagla, M.C.; Bera, S.K. Rectification of modified AMMI stability value (MASV). Indian J. Genet. Plant Breed. 2019, 79, 726-731.

28. Farshadfar, E. Incorporation of AMMI stability value and grain yield in a single non-parametric index (GSI) in bread wheat. Pak. J. Biol. Sci. 2008, 11, 1791-1796. [CrossRef] [PubMed]

29. Yan, W.; Kang, M.S. GGE Biplot Analysis: A Graphical Tool for Breeders, Geneticists, and Agronomists; CRC Press: Boca Raton, FL, USA, 2003

30. Joshi, A.K.; Chand, R.; Trethowan, R.; Vargas, M.; Ortiz-Monasterio, I. Genotype $\times$ environment interaction for zinc and iron concentration of wheat grain in eastern Gangetic plains of India. Field Crop. Res. 2010, 116, 268-277. [CrossRef]

31. Gomez-Becerra, H.F.; Erdem, H.; Yazici, A.; Tutus, Y.; Torun, B.; Ozturk, L.; Cakmak, I. Grain concentrations of protein and mineral nutrients in a large collection of spelt wheat grown under different environments. J. Cereal Sci. 2010, 52, 342-349. [CrossRef]

32. Gomez-Becerra, H.F.; Yazici, A.; Ozturk, L.; Budak, H.; Peleg, Z.; Morgounov, A.; Fahima, T.; Saranga, Y.; Cakmak, I. Genetic variation and environmental stability of grain mineral nutrient concentrations in Triticum dicoccoides under five environments. Euphytica 2010, 171, 39-52. [CrossRef]

33. Chakraborti, M.; Prasanna, B.M.; Hossain, F.; Mazumdar, S.; Singh, A.M.; Guleria, S.; Gupta, H.S. Identification of kernel iron-and zinc-rich maize inbreds and analysis of genetic diversity using microsatellite markers. J. Plant Biochem. Biotechnol. 2011, 20, 224-233. [CrossRef]

34. Agrawal, P.K.; Jaiswal, S.K.; Prasanna, B.M.; Hossain, F.; Saha, S.; Guleria, S.K.; Gupta, H.S. Genetic variability and stability for kernel iron and zinc concentration in maize (Zea mays L.) genotypes. Indian J. Genet. Plant Breed. 2012, 72, 421-428.

35. Singhal, T.; Satyavathi, C.T.; Kumar, A.; Sankar, S.M.; Singh, S.P.; Bharadwaj, C.; Aravind, J.; Anuradha, N.; Meena, M.C.; Singh, N. Genotype $x$ environment interaction.and genetic association of grain iron and zinc content with other agronomic traits in RIL population of pearl millet. Crop Pasture Sci. 2018, 69, 1092-1102. [CrossRef]

36. Gauch, H.G. A simple protocol for AMMI analysis of yield trials. Crop Sci. 2013, 53, 1860-1869. [CrossRef]

37. Gollob, H.F. A statistical model which combines features of factor analytic and analysis of variance techniques. Psychometrika 1968, 33, 73-115. [CrossRef] [PubMed]

38. Purchase, J.L. Parametric Analysis to Describe Genotype $\times$ Environment Interaction and Yield Stability in Winter Wheat. Ph.D. Thesis, Department of Agronomy, Faculty of Agriculture, University of the Free State, Bloemfontein, South Africa, 1997.

39. Purchase, J.L.; Hatting, H.; Van Deventer, C.S. Genotype $\times$ environment interaction of winter wheat (Triticum aestivum L.) in South Africa: II. Stability analysis of yield performance. S. Afr. J. Plant Soil. 2000, 17, 101-107. [CrossRef]

40. Zali, H.; Farshadfar, E.; Sabaghpour, S.H.; Karimizadeh, R. Evaluation of genotype $\times$ environment interaction in chickpea using measures of stability from AMMI model. Ann. Biol. Res. 2012, 3, 3126-3313.

41. Singh, A.; Sharma, V.; Dikshit, H.K.; Aski, M.; Kumar, H.; Thirunavukkarasu, N.; Patil, B.S.; Kumar, S.; Sarker, A. Association mapping unveils favorable alleles for grain iron and zinc concentrations in lentil (Lens culinaris subsp. culinaris). PLoS ONE 2017, 12, e0188296. [CrossRef] [PubMed]

42. Kumar, H.; Singh, A.; Dikshit, H.K.; Mishra, G.P.; Aski, M.; Meena, M.C.; Kumar, S. Genetic dissection of grain iron and zinc concentrations in lentil (Lens culinaris Medik.). J. Genet. 2019, 98, 66-78. [CrossRef]

43. Phuke, R.M.; Anuradha, K.; Radhika, K.; Jabeen, F.; Anuradha, G.; Ramesh, T.; Hariprasanna, K.; Mehtre, S.P.; Deshpande, S.P.; Anil, G.; et al. Genetic variability, genotype x environment interaction, correlation, and GGE biplot analysis for grain iron and zinc concentration and other agronomic traits in RIL population of sorghum (Sorghum bicolor L. Moench). Front. Plant Sci. 2017, 8, 712. [CrossRef] 
44. Anuradha, N.; Satyavathi, C.T.; Meena, M.C.; Sankar, S.M.; Bharadwaj, C.; Bhat, J.; Singh, O.; Singh, S.P. Evaluation of pearl millet [Pennisetumg laucum (L.) R. Br.] for grain iron and zinc content in different agro climatic zones of India. Indian J. Genet. Plant Breed. 2017, 77, 65-73. [CrossRef]

45. Ray, H.; Bett, K.; Tar'an, B.; Vandenberg, A.; Thavarajah, D.; Warkentin, T.D. Mineral micronutrient content of cultivars of field pea, chickpea, common bean, and lentil grown in Saskatchewan, Canada. Crop Sci. 2014, 54, 1698-1708. [CrossRef]

46. Kumar, H. Stability Analysis and Association Mapping of Grain Micronutrients (Fe and Zn) in Lentil (Lens culinaris Medikus subsp. culinaris). Ph.D. Thesis, IARI, New Delhi, India, 2015.

47. Purchase, J.L.; Hatting, H.; van Deventer, C.S. The use of the AMMI model and AMMI stability value to describe genotype $x$ environment interaction and yield stability in winter wheat (Triticum aestivum L.). In Proceedings of the 10th Regional Wheat Workshop for Eastern, Central and Southern Africa, University of Stellenbosch, Stellenbosch, South Africa, 14-18 September 1998.

48. Mallikarjuna, M.G.; Thirunavukkarasu, N.; Hossain, F.; Bhat, J.S.; Jha, S.K.; Rathore, A.; Agrawal, P.K.; Pattanayak, A.; Reddy, S.S.; Gularia, S.K.; et al. Stability performance of inductively coupled plasma mass spectrometry-phenotyped kernel minerals concentration and grain yield in maize in different agro-climatic zones. PLoS ONE 2015, 10, e0139067. [CrossRef]

49. Karimizadeh, R.; Mohammadi, M.; Shefazadeh, M.K.; Mahmoodi, A.A.; Rostami, B.; Karimpour, F. Relationship among and repeatability of ten stability indices for grain yield of food lentil genotypes in Iran. Turk. J. Field Crop. 2017, $17,51-61$.

50. Ajay, B.C.; Bera, S.K.; Singh, A.L.; Kumar, N.; Gangadhar, K. Evaluation of genotype x environment interaction and yield stability analysis in peanut under phosphorus stress condition using stability parameters of AMMI model. Agric. Res. 2020, 9, 477-486. [CrossRef] 